\title{
Child Writing and the Traumatised Body
}

\author{
Caroline Lieffers \\ Assistant Professor, The King's University
}

ON 9 August 1945, fourteen-year-old Ishida Masako' became a victim of the atomic bombing of Nagasaki. She documented her experiences in Masako taorezu: Nagasaki genshi bakudanki, variously rendered in English as Masako Does Not Give Up, Masako Does Not Collapse, or Masako Does Not Fall, among others. Begun in September 1945 for a family newspaper, the book was finally published in 1949 after a protracted battle with American military censors. The short memoir is a catalogue of horrors, including descriptions of a road "so littered with blackened corpses that we encountered one at every step," and "the charred remains of mothers still holding their babies and people who had died clutching the ground in throes of pain" (Ishida 233). Unlike so many other survivors, Ishida—exhausted and covered with scrapeswas soon reunited with her relatives, but her struggles would continue. She described the terrible head and muscle aches that she experienced as she lay in bed in the days after the bombing, and her feeling of "wobbling between life and death" (227). "You've suffered only superficial wounds," said her sister's tutor, Ms. Hayashi. "You can't let yourself become so depressed. Pull yourself together. I think you are exaggerating a little." But Ishida knew better. She wrote that "the pain was terribly real, and there was nothing I could do to drum up strength" (226). Sick with wounds and radiation poisoning that she described as "agonizing" (215), Ishida began to recover under the care of her relatives, but her white blood cell count remained low. She spent a month in the medical clinic at Kyushu University and continued her convalescence until the following March.

Texts by young conflict survivors like Ishida are worthy of historical and literary consideration on many fronts. Heavy with the burden of trauma, these works often reveal intimate knowledge of war and its pain, the politics of rebuilding, and the quiet,

\footnotetext{
${ }^{1}$ In Japanese, family names traditionally precede given names. This essay adheres to this convention.
}

(cc) Lieffers. This article is distributed under a Creative Commons Attribution-NonCommercialNoDerivatives 4.0 International Licence (creativecommons.org/licenses/by-nc-nd/4.0/).

Journal of Juvenilia Studies 4.I (202I), pp. 25-3I. DOI: I0.29I73/jj556 


\section{JJS December (202I) Special Issue: Juvenilia, Trauma, and Intersectionality}

even unutterable, legacies of loss. Somewhat unusually for children's writing, they can also contain significant first-hand descriptions of bodily injury, pain, and even disability. How did young people experience, understand, and cope with damage to their bodies? What stigma did they face, and what emotional or philosophical scripts did they pursue or devise to make sense of their injuries and their changed futures? How did they translate their deeply embodied and arguably indescribable feelings into prose, and how did they negotiate the meanings that such prose held within societies and cultures that had undergone collective trauma and transformation? This special issue suggests that juvenilia offer a deep well for other fields - trauma studies, the history of childhood, and even disability studies - to consider, and juvenilia studies might also deepen its own analyses by incorporating new theoretical apparatuses that can help elucidate the personal, social, and political implications of young writers' experiences of trauma and injury.

To study children's writings about their traumatised bodies is to engage a complex locus of existence and expression. Cathy Caruth explains that trauma involves "a history [that] can be grasped only in the very inaccessibility of its occurrence" (8). Similarly, James Berger writes that trauma theory might be understood as "a vehicle for catachresis, for a saying [sic] the unsayable, or saying that for which no terms exist" (567). Trauma is, almost by definition, beyond articulation; it can be witnessed only through its retrospective construction or narration, at a distance, or through its symptoms-palimpsests that, present though they may be, can never fully represent the original events. Embodiment and its expressions, however, might be a concrete point of access into the largely abstract experience of trauma. Juvenile survivors of the bombings of Nagasaki and Hiroshima offered up tentative but powerful descriptions of acquiring and living with their wounds, illnesses, and scars, as well as glimpses of the accompanying psychic and social pain, both at the time of the bombings and beyond.

In examining trauma's embodiments in young people's writing, juvenilia studies might find meaningful overlap not only with trauma studies, but also with the history of childhood and emotion. The intersection of these fields is a nascent project, marked by important works like historian Stephanie Olsen's 2017 essay, “The History of Childhood and the Emotional Turn." Much of this emerging scholarship has sought to understand how children's emotions respond to, reinforce, or defy social expectations. But while historians of childhood have all too often been starved for intimate records of children's experiences of emotion, the field of juvenilia studies has situated itself at precisely that point of access, privileging as it does the rich inner lives articulated by child writers. Much of juvenilia studies has admittedly and understandably focused on fiction and imagined worlds, but scholars of juvenilia and childhood emotion, perhaps without realising it, are pursuing many of the same questions, albeit with different methodologies. What do children think and feel? How are these thoughts shaped by their environments, and how are they expressed? Attention to children's writing about their injured bodies, as well as the emotional 


\section{Editor's Column | Lieffers}

force and significance of such descriptions, may approach the asymptote of their trauma, and offer insights for scholars working from numerous disciplinary points of origin.

Children's writings about Hiroshima and Nagasaki in particular testify to the deep human toll that the bombs wrought; in Ishida's case, this trauma continued, to some extent, through her medical care. After she first entered the hospital in September 1945, she was delighted with her slowly climbing white blood cell count and, perhaps more importantly, the rich hospital food. After wartime rationing, the dishes seemed extravagant, and she listed them breathlessly: "sushi, flavored rice, rice with chestnuts, rice with red beans, fried rice, sweet soup, tempura, steamed bread with Yukijirushi butter, tekka-miso, sukiyaki, sashimi, fried eel, chicken shish kabob, pancakes, eggs, canned yellowtail, steamed sweet potatoes, German canned salmon streaked with fat, milk, persimmons .... I ate anything and everything made available to me" (Ishida 220). The novelty, however, soon wore off. Though Ishida was feeling better, she was given experimental injections of what she described as "liver hormones" (219). The injection site grew swollen and uncomfortable, and she was also asked to swallow a long rubber tube to allow doctors to examine her stomach fluid. It caused her to gag, but the medical experts kept trying to complete the procedure for several hours. Frustrated and worried, she wrote to her father, pleading for help: "If I stay here they will keep using me as a guinea pig like this" (217). Her father arranged for her release within a week.

Ishida was the victim of horrific wartime violence, violence that also doubled as a grotesque and uncontrolled experiment on the effects of nuclear explosions on human life. Survivors bore the stigma and responsibility of harbouring the A-bomb's terrifying and heretofore unknown consequences, as well as being what historian John Dower calls "deformed reminders of a miserable past" (128). Much of the medical care in the initial aftermath of the bombings was similarly experimental, and Ishida experienced this care as a series of frightening, painful, and, to her mind, unnecessary procedures. Much of her knowledge of what was happening came from rumours, and she had little control of her situation: when a nurse suddenly appeared in her room to give her an injection, she wrote, "I had no choice but to lie face down on the bed" (219). American medical teams were also gathering information about the bombs' effects, and this research was formalised with the creation of the Atomic Bomb Casualty Commission in 1946. This organisation ostensibly worked in partnership with Japanese medical experts to monitor the explosions' effects on the population. Physicians took careful notes and photographs of burns and wounds, measured white blood cell counts, and documented damage to organs. But many of the bombs' victims, like Ishida, felt vulnerable in the face of medical authorities' investigations. The Atomic Bomb Casualty Commission, in fact, would not treat the victims of Hiroshima and Nagasaki; the Americans feared that treatment would be interpreted as a kind of atonement or admission of wrongdoing, and they were also supposedly worried about taking jobs from Japanese physicians (Lindee 475, 478). Many 


\section{JJS December (202I) Special Issue: Juvenilia, Trauma, and Intersectionality}

survivors were left on their own to negotiate their suffering and their futures, haunted by the sense that they had been, and continued to be, objects of a grand experiment in warfare and medicine alike.

Though Ishida eventually recovered physically, the same was not true of all child survivors of Hiroshima and Nagasaki, many of whom bore scars or other permanent evidence of their injuries. Scholars of disability history and disability studies have noted the pervasiveness of stigma-including among atomic bomb victims-as bodies that do not fit normalised modes of productivity and aesthetics are shunned or targeted for repair (e.g. Serlin, ch. 2). Yet the matter of grief has been less well documented. Indeed, disability studies and critical trauma studies have often been at odds, given the former's emphasis on the politics of socially constituted impediments and oppressions. In 2004, Berger called this a "mutual exclusion that constitutes a discursive abyss" (563). While this "discursive abyss" may be beginning to close, few disability historians have examined the emotional lives of disabled children, or the ways that child survivors of trauma made sense of their newly altered and marked bodies, or the altered and marked bodies of others. These visceral experiences had political and social causes and consequences, but they were also intimately and personally felt, known, and expressed. Child writing is an important avenue into a disability studies and disability history with dimensions beyond the political and the social.

Yet Ishida's story suggests that personal testimonies of the atomic bombings and the individual work of knowing and narrating grief could not be separated from national trauma and the collective politics of rebuilding. Initially, public accounts of the bombs' effects were often delayed or suppressed, both within and outside Japan. Survivors' accounts of those days of destruction, as well as information about the serious and long-term health effects of the atomic blasts, might damage both America's reputation and Japan's recovery efforts. But the damage was already marked on the bodies and minds of countless young people, and many, like Ishida, took up their pens to express what they had known and felt. For some, this writing was an intimate project, while other children were encouraged to write as an exercise in personal growth and publicly practised citizenship. Indeed, in 1951, Osada Arata, a professor of education at Hiroshima University, solicited thousands of testimonies from young people who had survived the blast in Hiroshima. Though some were reluctant writers, Osada ultimately published 105 of these personal stories in his edited collection, Genbaku no ko (Children of the A-Bomb), which he saw as an essential contribution to the movement for global peace.

Ishida, it should be noted, did not initially want to tell her story, but she was convinced to do so by her brother Joichi, who put together a family newspaper to share among relatives scattered by work and the war. They were eager for her account, and Ishida seemingly understood that her survivorship was meaningful, and that she had an obligation to write for others. She began her four-part narrative while she was still in the hospital, and she finished it in late 1945 or early 1946. In an interview for 


\section{Editor's Column | Lieffers}

a Japanese newspaper article in 2014, she said, "There were many things that I didn't write; my arm was hurting from writing and I didn't want to recall it all. I skipped many details and only wrote the main points, but I saw them so clearly" (qtd. in Okada). It is difficult to assess Ishida's intentions and her sense of control as she composed her text. Though her memories of the events were seemingly unobscured, her physical and psychic pain imposed a kind of selectivity on her writing. It may have taken years for Ishida to be able to assess and articulate more fully what she felt about the things that she saw so clearly - the burning buildings, the abandoned friends. Indeed, in the 2014 interview, she confessed that she struggled for years with feelings of remorse, as she could not save the other students and women who died in the fire at the factory where she was working. "I abandoned them; and up to now, I have suffered from a tremendous sense of guilt," she explained (qtd. in Okada). In contrast to these more direct statements, made in her old age, Ishida's sense of culpability and responsibility lingers only in the background of Masako taorezu. When a woman factory worker cries to Ishida, "Forget about me and save yourself," Ishida narrates simply, "But it was not easy for anyone to go ahead" (245). That night, as she waited to board a relief train, she notes that she "had forgotten all feelings of shock, pity or compassion" (238). Only years later was she able to recognise the presence of these emotions more explicitly, and the ways that they had haunted her life.

But even with these partial revelations and weighty silences, the significance of Ishida's story was soon evident among her family members. In a letter to the young author, her cousin Tanabe Kenichi wrote that "Perhaps the old Masako died that day in Nagasaki, along with the old Japan. The atomic bombs were like hammers that crushed the evils of old Japan" (qtd. in Ishida 215). Ishida's survival, and particularly her body-its witness, its injuries, and its recovery - were metaphors for the nation as a whole, and their meanings could not belong to her alone. Appearing near the end of her text, her cousin's letter is juxtaposed with her own, quiet reflections. After a long convalescence, she was taking the train back to Nagasaki to begin a new school year, and thinking about "all the things that had happened to date." There was the explosion and devastation at the factory, the tunnel where she found shelter on the night after the bombing, the "agonizing days of acute illness," and the "uplifting hospital life" (214-15). These were, she wrote, "my precious experiences and lessons in life" (215), and she knew they were lessons for her readers, too. Yet Ishida recognised that being able to derive some sense of meaning from her experience was not the same thing as resolution. As the train approached the place where she once took refuge, her narrative ends with the statement that "the painful scenes of that morning outside the tunnel came to mind again ..." (214). Her account would not reveal the fullness of her memories and her pain.

Ishida was writing for her family, but it was her father, Hisashi, a judge, who pressed for her story to be published more widely. Perhaps he believed that her narrative of having "emerged victorious over the wrath of the atomic bomb and the blight of radiation," as her brother Joichi put it, deserved a national audience, and it 


\section{JJS December (202I) Special Issue: Juvenilia, Trauma, and Intersectionality}

might serve as inspiration for a country similarly in the process of constructing a new future for itself (qtd. in Ishida 214). Her father arranged for numerous civic leaders in Nagasaki to sign a letter in support of publication (Okada), but the District Censor recommended suppression on the grounds that the book might disrupt "public tranquillity" (qtd. in Braw 99). Though some members of the American military government team in Nagasaki disagreed, the authorities responsible for censorship feared that Ishida's graphic depictions - the raw flesh, the rivers bursting with corpses - could "tear open war scars and rekindle animosity" (qtd. in Braw 99). The very wounds that so many survivors were forced to bear in their own bodies and minds were not allowed to exist in public prose. They were confined to unruly flesh, and in survivors' silenced memories.

The censors finally relented in 1949, as the rules loosened and authorities concluded that it was better to allow "resentment, or even enmity" to be aired out rather than left to fester (Braw 151). The text also underwent a few minor changes, likely at the hands of Ishida's father: "devilish atomic bomb," for example, became "horrible atomic bomb" (Okada). But Ishida herself appears to have been ambivalent about her account. The 2014 newspaper article notes that "she never thought that her memoir would become a book" (Okada), and she had little understanding of the censorship debate; she only realised that her story had been published when she came across a few hundred copies piled in the corner of their house (Okada). Her reluctance then turned to regret. Realising the gravity of such testimony and the guilt of having survived, she said, "I was ashamed that I didn't write about everything. There were so many people who had to face much more terrible situations than I was in, and showing mine as a memoir seemed ridiculous" (qtd. in Okada). Her account had become part of national memory, and she felt she had failed to honour the wounds of others, or to fulfill her own responsibility to witness fully to such a grave event. After having such little control over her experience and the book that recounted it, she chose not to speak publicly about either for decades. It was only in her advanced age that she began to tell her story again, and came to appreciate that her work had served a valuable purpose: "When something remains in print, then someday someone will read it. Then they will know that such an event took place" (qtd. in Okada).

Children's traumatised bodies are powerful objects and subjects. They can be concrete remembrances of horror, sites experienced and interpreted by the individual and society and flooded with emotional, political, and even spiritual significance. Young people's experiences and accounts of trauma, moreover, are embedded in complex networks of self, family, and nation. They hold extraordinary, even dangerous power, but they are unstable nuclei, with meanings and forms that might shift over decades. Juvenilia is a rich and rare vein through which to trace children's experiences and understandings of this bodily damage and its deeper meanings. Combining the literatures of trauma, the history of childhood emotion, and disability 


\section{Editor's Column | Lieffers}

with juvenilia studies holds extraordinary potential for all fields, and for our collective capacity to know and honour wounded children's lives and writings.

\section{WORKS CITED}

Berger, James. "Trauma Without Disability, Disability Without Trauma: A Disciplinary Divide." JAC, vol. 24, no. 3, 2004, pp. 563-82.

Braw, Monica. The Atomic Bomb Suppressed: American Censorship in Japan, 1945-1949. Malmo, Liber Förlag, 1986.

Caruth, Cathy. Trauma and Experience: Introduction. Trauma: Explorations in Memory, edited by Cathy Caruth. Johns Hopkins University Press, 1995, pp. 3-12.

Dower, John W. "The Bombed: Hiroshimas and Nagasakis in Japanese Memory." Hiroshima in History and Memory, edited by Michael J. Hogan. Cambridge UP, 1996, pp. 116-42.

Ishida Masako. "Masako Does Not Give Up: The 'Ishida Newspaper' Version.” Translated by Brian Burke-Gaffney. Nagasaki, sono toki no hibaku shōjo: rokujügonenme no "Masako taorezu". Tokyo, Jiji Tsūshin Shuppankyoku, 2010, pp. 213-50.

Lindee, M. Susan. "Atonement: Understanding the No-Treatment Policy of the Atomic Bomb Casualty Commission." Bulletin of the History of Medicine, vol. 68, no. 3, 1994, pp. 454-90.

Okada, Shohei. "Notes from Nagasaki: Masako Does Not Collapse ... Beyond Censorship." The Asahi Shimbun, July 2014, www.asahi.com/hibakusha/english/shimen/nagasakinote/note90-08e.html.

Olsen, Stephanie. "The History of Childhood and the Emotional Turn." History Compass, vol. 15, no. 11, 2017, e12410. doi: 10.1111/hic3.12410.

Osada Arata, editor. Children of the A-Bomb: Testament of the Boys and Girls of Hiroshima, translated by Jean Dan and Ruth Sieben-Morgen. Tokyo, Uchida Rokakuho, 1959.

Serlin, David. Replaceable You: Engineering the Body in Postwar America. U of Chicago P, 2004. 